\section{A Marker Gene in Southern Dewberry (Rubus trivialis Michx.)}

\author{
Creighton L. Gupton ${ }^{1}$ \\ U.S. Department of Agriculture. Agricultural Research Service, Small Fruit \\ Research Station, P.O. Box 287, Poplarville, MS 39470
}

Additional index words. blackberry, small fruit breeding, anthocyanin

\begin{abstract}
Anthocyanin-deficient dewberries in Mississippi were evaluated for possible use as a source of marker genes for blackberries. Ratios of normal to anthocyanin-deficient plants from test crosses suggested single-locus control of stem color, with anthocyanin deficiency a recessive trait. Its simple inheritance and easy identification in seedlings provide potential for anthocyanin deficiency $(t)$ to be used as a marker gene in blackberry genetic studies.
\end{abstract}

The southern dewberry is a diploid species characterized as having habitually trailing canes with red bristles present in addition to spines (Blomquist and Oosting, 1959) (Fig. 1, top). Its fruit is a typical blackberry that originates from a solitary flower (Blomquist and Oosting, 1959). In recent years, albino dewberries have been found growing in fence rows on three farms in Pearl River County, Miss., by the fence owners and in Texas (Marty Baker, Texas A\&M Univ., Overton, personal communication). The bristles and spines on their canes are green (Fig. 1, bottom) and the berries are almost translucent when ripe (Fig. 2 ). Anthocyanin-deficient plants can be identified as seedlings, an ideal trait to serve as a genetic marker, providing it is inherited simply. 'Albino White', a hardy dewberry type, was introduced by Henderson's Nursery, Athens, Texas, about 1930. 'Crystal White', an upright blackberry variety with dull amberwhite-colored fruit (apparently developed in the 1800s) was evaluated in Nacogdoches, Texas (Morris, 1938). The Mississippi anthocyanin-deficient dewberry clones were studied to determine their possible use as a source of marker genes for blackberries.

\section{Materials and Methods}

Albino dewberries from separate farms, designated Bonnette (BON) and Harriel $(\mathrm{H})$, were crossed with each other and with a redcaned dewberry (DB). $F_{1}$ plants were testcrossed (Table 1). Red : green stem ratios within each test cross were tested for goodness of fit to expected ratios (assuming anthocyanin deficiency was controlled by a recessive gene at a single locus) by $\chi^{2}$ analyses by Yates

Received for publication 7 Apr. 1995. Accepted for publication 13 June 1995. The cost of publishing this paper was defrayed in part by the payment of page charges. Under postal regulations, this paper therefore must be hereby marked advertisement solely to indicate this fact.

${ }^{1}$ Research Geneticist. correction for continuity (Little and Hills, 1978). Total, pooled, and heterogeneity $\chi^{2}$ then were computed. a plant with anthocyanin deficient bristles and spines.
All 62 plants produced by the $\mathrm{DB} \times \mathrm{H}$ cross and all 59 plants produced by $\mathrm{BON} \times \mathrm{DB}$ had red canes. $\mathrm{BON} \times \mathrm{H}$ produced nine plants, all with green canes. These results suggested that red cane was dominant to green cane and that the green canes of BON and $\mathrm{H}$ were produced by the same homozygous recessive genes. Inbreeding apparently reduced the number of plants recovered from the test crosses (Table 1). Although only a limited number of plants were produced from each test cross, there was no statistical evidence against the expected ratios. Pooled $\chi^{2}$ for crosses expected to segregate 1 red : 1 green and 3 red : 1 green supported the hypothesis of single locus of control of stem color. Heterogeneity $\chi^{2}$ suggested that all of the progenies represent samples from a single population. In the cases where reciprocal crosses were made, the red : green stem ratio was the same, indicating no maternal genetic effects.
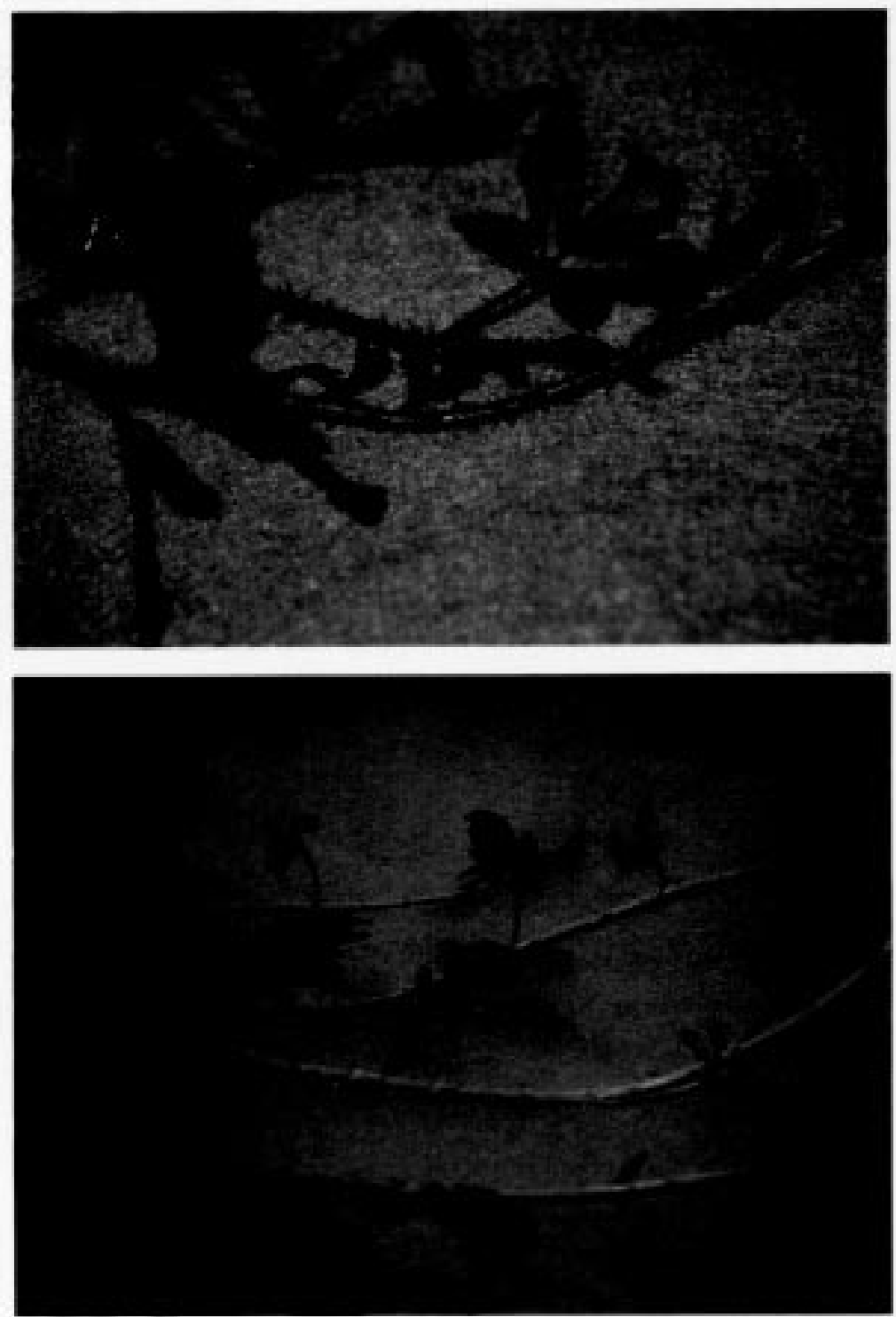

Fig. 1. Cane morphology and pigmentation of a (top) typical southern red-caned dewberry plant; (bottom) 


\section{Breeding, Cultivars, Rootstocks, \& Germplasm Resources}

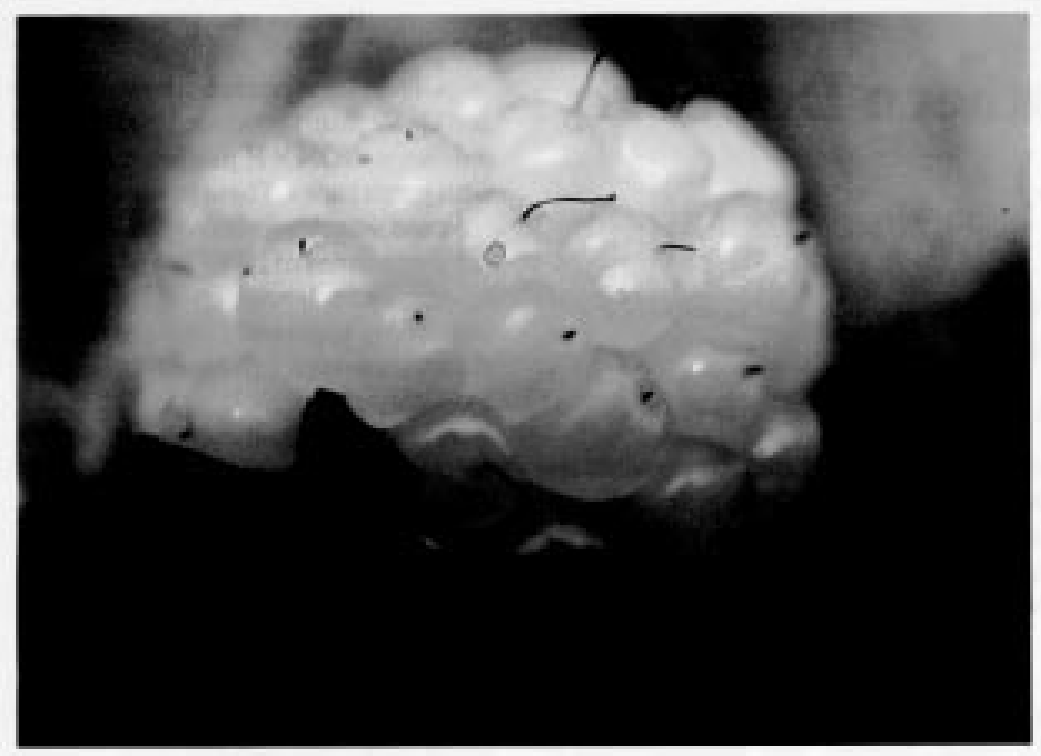

Fig. 2. Anthocyanin-deficient dewberry fruit that is almost translucent when ripe.
Anthocyanin deficiency in dewberry seems to be controlled by a single recessive gene that produces classical Mendelian ratios in crosses. A recessive allele $t$, known to cause a low concentration of anthocyanins (Jennings, 1988), giving yellow fruit and stems with nonpigmented spines, is probably responsible for the mutant trait. Its simple inheritance and easy identification in seedlings provide potential for anthocyanin deficiency $(t)$ to be used as a marker gene in blackberry genetic studies.

\section{Literature Cited}

Blomquist, H.L. and H.G. Oosting. 1959. A guide to the spring and early summer flora of the Piedmont, North Carolina. Seeman Printery, Durham, N.C.

Jennings, D.L. 1988. Raspberries and blackberries: Their breeding, diseases, and growth. Academic, New York.

Little, T.M. and F.J. Hills. 1978. Agricultural experimentation. Wiley, New York.

Morris, H.F. 1938. Blackberry and dewberry varieties in east Texas. Texas Agr. Expt. Sta. Bul. 558.

Table 1. Results of test-crossing $\mathrm{F}_{1}$ plants from normal dewberries (DB) and anthocyanin-deficient [designated Bonnette (BON) and Harriel (H)] dewberries.

\begin{tabular}{|c|c|c|c|c|c|c|c|c|}
\hline \multirow[b]{3}{*}{ Cross } & \multirow{3}{*}{$\begin{array}{c}\text { Presumed } \\
\text { genotype }\end{array}$} & \multicolumn{4}{|c|}{ Bristle and spine color } & \multirow[b]{3}{*}{$\chi^{2}$} & \multirow[b]{3}{*}{$\mathrm{df}$} & \multirow{3}{*}{$\begin{array}{r}\text { Probability of } \\
\text { larger value } \\
\end{array}$} \\
\hline & & \multicolumn{2}{|c|}{ Observed } & \multicolumn{2}{|c|}{ Expected } & & & \\
\hline & & Red & Green & Red & Green & & & \\
\hline$(\mathrm{DB} \times \mathrm{H}) \times(\mathrm{BON} \times \mathrm{H})$ & $\mathrm{Tt} \times \mathrm{tt}$ & 12 & 10 & 11 & 11 & $0.227^{2}$ & 1 & $0.90-0.50$ \\
\hline$(\mathrm{BON} \times \mathrm{DB}) \times \mathrm{BON}$ & $\mathrm{Tt} \times \mathrm{tt}$ & 2 & 1 & 1.5 & 1.5 & 0.667 & 1 & $0.50-0.10$ \\
\hline $\mathrm{BON} \times(\mathrm{BON} \times \mathrm{DB})$ & $\mathrm{tt} \times \mathrm{Tt}$ & 2 & 3 & 2.5 & 2.5 & 0.400 & 1 & $0.90-0.50$ \\
\hline$(\mathrm{DB} \times \mathrm{H}) \times \mathrm{BON}$ & $\mathrm{Tt} \times \mathrm{tt}$ & 5 & 6 & 5.5 & 5.5 & 0.181 & 1 & $0.90-0.50$ \\
\hline $\mathrm{BON} \times(\mathrm{DB} \times \mathrm{H})$ & $\mathrm{tt} \times \mathrm{Tt}$ & 3 & 2 & 2.5 & 2.5 & 0.400 & 1 & $0.90-0.50$ \\
\hline Total & & & & & & 1.006 & 5 & $0.99-0.95$ \\
\hline Pooled & & 24 & 22 & 23 & 23 & 0.087 & 1 & $0.90-0.50$ \\
\hline Heterogeneity & & & & & & 0.919 & 4 & $0.95-0.90$ \\
\hline$(\mathrm{DB} \times \mathrm{H}) \times(\mathrm{BON} \times \mathrm{DB})$ & $\mathrm{Tt} \times \mathrm{Tt}$ & 2 & 0 & 1.5 & 0.5 & $2.000^{z}$ & 1 & $0.50-0.10$ \\
\hline$(\mathrm{BON} \times \mathrm{DB}) \times(\mathrm{DB} \times \mathrm{H})$ & $\mathrm{Tt} \times \mathrm{Tt}$ & 1 & 1 & 1.5 & 0.5 & 0.667 & 1 & $0.50-0.10$ \\
\hline Total & & & & & & 1.334 & 2 & $0.90-0.50$ \\
\hline Pooled & & 3 & 1 & 3 & 1 & 0.000 & 1 & 1.00 \\
\hline Heterogeneity & & & & & & 1.334 & 1 & $0.50-0.10$ \\
\hline
\end{tabular}

${ }^{2}$ Chi-squared for individual test crosses adjusted by Yates correction for continuity. 